\title{
Romanian prime minister accused of plagiarism
}

\section{Allegations prompt questions about government's ability to tackle misconduct in academia.}

\section{BY QUIRIN SCHIERMEIER}

$\mathrm{R}$ omania's new government, still reeling from a misconduct scandal that forced its research minister to resign last month, has been hit by fresh allegations of plagiarism that strike at the very top.

Prime Minister Victor Ponta has been accused of copying large sections of his 2003 $\mathrm{PhD}$ thesis in law from previous publications, without proper reference. If the charges are substantiated, they could spark public pressure for Ponta to resign, say political insiders. The allegations are also raising fresh doubts about the government's ability to tackle corruption in the higher-education system.

Nature has seen documents compiled by an anonymous whistle-blower indicating that more than half of Ponta's 432-page, Romanianlanguage thesis ${ }^{1}$ on the functioning of the International Criminal Court consists of duplicated text. Moreover, the thesis was republished with very minor amendments as a Romanian-language book in 2004 (ref. 2), and also forms the basis of a 2010 book on liability in international humanitarian law ${ }^{3}$. A former PhD student of Ponta's, Daniela Coman, is named as co-author of the books.

Substantial sections of text in all three publications seem to be identical, or almost so, to material in monographs written in Romanian by law scholars Dumitru Diaconu ${ }^{4}$ and Vasile Crețu ${ }^{5}$. They also feature direct Romanian translations of parts of an English-language publication by law scholar Ion Diaconu'.

"The evidence of plagiarism is overwhelming," says Marius Andruh, a chemist at the University of Bucharest and president of the Romanian council for the recognition of university diplomas. If the allegations are borne out, "a serious discussion is needed in Romania

and abroad to prevent this in the future," says Andruh.

"I understand that in law studies it can be necessary to copy extensive legal articles and definitions," says Paul Dragos Aligica, a Romanian political scientist at George Mason University in Arlington, Virginia. But Ponta's alleged plagiarism "goes way beyond that. It's astonishing", he adds. Ponta did not respond to Nature's request for comment on the allegations, and Coman could not be contacted.

Ponta, leader of the Romanian Social Democratic Party, took office as prime minister only last month, replacing Emil Boc, who stepped down in February following protests against austerity measures that he had introduced.

"There is very clear evidence in these excerpts that the matter should be investigated further."

Ponta obtained his

$\mathrm{PhD}$ from the University of Bucharest while acting as Secretary of State in the government of an earlier prime minister, Adrian Năstase who was also his $\mathrm{PhD}$ supervisor.

"There is very clear evidence in these excerpts that the matter should be investigated further," says Vlad Perju, a Romanian political scientist and director of the Clough Center for the Study of Constitutional Democracy at Boston College in Chestnut Hill, Massachusetts.

The episode follows the resignation last month of the education and research minister, computer scientist Ioan Mang, following accusations of plagiarism in at least eight papers ${ }^{7}$. An investigation of that case by the Romanian Research Ethics Council is ongoing.

The latest allegations add to complaints about declining academic standards in Romania. The previous government had introduced measures to make the country's struggling science and education system more competitive and transparent, but the plans met ferocious opposition from large parts of the academic establishment, and have been substantially relaxed by the current government.

"It's more than unlikely that this government is fit to create institutional structures in science that Romania urgently needs," says Aligica. "How can it be, when some of its leaders don't seem to even remotely understand, or care about, the standards of good science?"

Members of Romania's post-communist elite - including many politicians - have been eager to acquire academic credentials. In the view of some critics, a number of private and public universities in the country are consequently degenerating into 'degree mills' that care little about the quality or novelty of the knowledge that they produce, and which are a breeding ground for academic plagiarism.

"One could almost feel pity for all these guys who have power and money, and who are now craving intellectual recognition," says Aligica. "Unfortunately these incidents just add to the disrepute of Romanian academic standards and create extra pressure that real Romanian scholars and scientists will now have to fight against." -

1. Ponta, V. Curtea Penală Internaționala. PhD thesis, Univ. Bucharest (2003).

2. Ponta, V. \& Coman, D. Curtea Penală Internaționala (Lumina Lex, 2004).

3. Coman, D. \& Ponta, V. Răspunderea în Dreptul Internaţional Umanitar (Universul Juridic, 2010)

4. Diaconu, D. Curtea Penală Internaționlă, Istorie şi Realitate (Editura All Beck, 1999).

5. Crețu, V. Drept Internațional Penal (Editura Tempus, 1996).

6. Diaconu, I. The International Criminal Court: A New Stage (Nicolae Titulescu Romanian Inst. International Studies, 2002).

7. Abbott, A. Nature 485, 289 (2012)

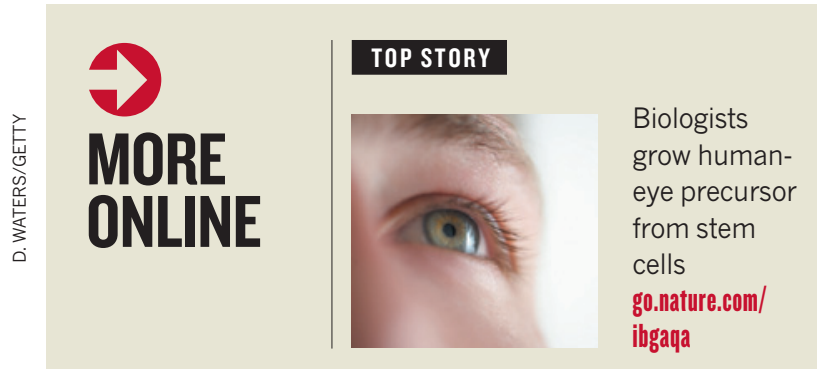

\section{MORE NEWS}

- Budget cuts threaten Japanese scientists' pay go.nature.com/ahwioz - Risk assessment of US agrobiosafety lab found wanting go.nature. com/ozze9w

- Boron finally gets a triple bond go.nature.com/3motmh

\section{NEWS SPECIAL}

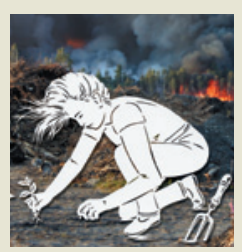

Rio+20 Earth summit kicks off in Brazil, with low expectations of progress go.nature.com/ d69weu 